\title{
SCIENCE
}

\begin{abstract}
Friday, November 24, 1911
CONTENTS

University Administration and University Ideals: Dr. Stuart Paton ............ 693

Physiology as a Fundamental in Veterinary Education: Professor Pierre A. Fish ... 700

Additional Facts about the Chestnut Blight:

I. C. Willinams .................. 704

The Sarah Berliner Fellowship: C. L. F. ... 705

A Field School of Geology .............. 706

Wisconsin Geological and Natural History Survey $. . . \ldots \ldots \ldots \ldots \ldots \ldots \ldots \ldots, 706$
\end{abstract}

The Will of Mr. Joseph Pulitzer ........ 707

Scientific Notes and News ............ 708

University and Educational News ....... 712

Discussion and Correspondence:-

The Exiled Naturalists of Portugal: ProFESSOR T. D. A. Cockerell. "Domesticated Animals and Plants"': Professor E.

Davenport ..................... 714

Quotations:-

Pensions and the Learned Professions ... 715

Scientific Books:-

Leonhardi Euleri, Opera Omnia: Professor G. A. MILLER: Thompson's Applied Electrochemistry: Professor SAMUel A. TUCKer. Lippincott's New Medical Dictionary: Dr. Felix Neumann ................ 717

The Meeting of the Association of American Universities 720

Special Articles:-

The Rôle of Different Proteins in Nutrition and Growth: Professor Thomas B. OsBorne, Professor Lafayette B. Mendel . 722

MSS. intended for publication and books, etc., intended for review should be sent to the Editor of ScIENCE, Garrison-onHudson, N. Y。

\section{UNIVERSITY ADMINISTRATION AND UNIVERSITY IDEALS}

THE development of our American universities is seriously handicapped by the present system of administration. A spirit of chauvinism intolerant of adverse criticism from outsiders, even when directed against obvious defects, is often a prominent factor in determining as well as in limiting the functions of the entire educational system now operative in colleges and universities which remain private corporations. This particular defect is more apparent in our older universities where the bonds of union between alma mater and alumni, which during the early period of development were essential to the life of our colleges, now threaten unless modified and readjusted to impair the growth and vitality of these institutions. Wherever the spirit of progress is felt, the problem of the proper readjustment of the administrative forces of our universities so as to make the most effective use of available resources is, for the moment, a more important question than providing for an increase of revenue. It is not difficult to point out more than one concrete example of the confusion that exists in regard to the relationships of the various departments of administration and the unfortunate state of anarchy sure to arise when a board of trustees whose members are uninformed as to the general progress made in the development of universities suddenly reassumes the powers which through their inertia had temporarily been relegated to president and deans. The results of this unfortunate state of affairs have been that fruitless efforts are made to solve problems requiring the training and special knowledge 
possessed only by experts in university affairs.

The administration of our universities is vested in a board of trustees, a corporation, or overseers, president and faculty. The manner in which the members of these boards are selected and the relation they bear to each other is not the result of a carefully thought-out plan, but represents a scheme in development in which opportunism has played the chief part. A serious result of a policy of administration that takes no thought for the morrow is seen in the persistence of a form of government sufficiently elastic not to interfere with the growth of the college, but painfully restrictive when applied to the conduct of affairs in the higher institutions of learning. The form of organization, with but very slight modifications, that was originally adopted in the early history of our colleges, when these institutions were about on the level with our present high schools, is practically in use now and is relatively as effective as would be the woodburning locomotive in pulling the modern express train. The present relationship between the faculty, trustees and president may be regarded as a haphazard growth, the result of a laissez-faire policy, affording an example of the same sufficient-tothe-day spirit and smug satisfaction with existing conditions that is so common in our institutions, and is well illustrated in the administration of municipal affairs where the immediate exigencies of a given situation are met without any provision for eventualities.

The chief duty of the trustees during the early history of the American colleges was to assist the president in collecting the necessary revenues, while turning to him for instruction in regard to the educational policy of the college. He became not alone their representative and spokesman, but also that of the faculty. The present autocratic position of university executives was created for them by the acts of the trustees in shifting responsibility for the performance of certain duties from their own shoulders to that of the president and deans.

The faculty, to an almost equal degree, is to blame for the undue centralization of power in the executive offices. As a rule, faculties (in common with other legislative bodies long deprived of constitutional rights) as a body, are nihilistic and show little evidence of any capacity for constructive criticism and administration. During the period when the autocracy of the president's and dean's office was rapidly rising, it became a form of lèse-majesté, as it is now, for members of the faculty to communicate their views upon university questions to individual members of the board of trustees. As all direct channels of communication between trustees and faculty are officially closed, the temptation to resort to indirect methods of expression and interchange of ideas is frequently present.

The ease with which the members of the board of trustees transferred their power as well as sense of obligation in the performance of duties to the president plainly showed they did not wish to be troubled unnecessarily by the discussion of educational problems. The lack of sympathetic interest shown by the trustees in the problems of most vital importance in the university life has had two serious consequences. In more than one instance a feeling of distrust and suspicion has arisen between the faculty and trustees, more serious and aggravated in the case of the former body, as they as individuals were directly interested in the progress of events. In the second place the absence of any safety valve or of a channel of direct com- 
munication between the two governing boards has given rise within the faculty to a psychasthenia universitatis. This psychosis has been produced by the lack of opportunity to discuss the larger problems of the university, and as always happens to those suffering from forms of mental repressions, or of living in cramped intellectual quarters, the tendency to indulge in petty recriminations and to be resentful of criticism has occasionally assumed alarming proportions with some of the characteristics of an epidemic. If it were possible to adopt the treatment generally indicated in psychoses of this nature, a cure could readily be effected by getting rid of the relatives and asking for advice from disinterested outsiders competent to express an opinion on university problems. Unfortunately, complications are apt to arise. Trustees, unaccustomed to the discussion of academic problems, will, when confronted by a crisis, feel the importance of immediate action. The faculty naturally resents what it considers to be an encroachment upon its prerogatives, and well-grounded serious misgivings as to the results that will probably follow the interference of laymen in the struggle for the establishment and maintenance of university ideals are sure to arise.

At present, trustees see things through a glass very darkly, as they themselves are generally strong partisans of institutions and lack not only a special knowledge of university problems, but are often deficient in a true sense of perspective. The choice of trustees in our eastern universities in a large number of instances is not determined by the individual's personal qualifications for the position, nor by his special knowledge of university problems. The selection depends frequently upon the partisanship of the candidate reflected in the uncritical attitude of devotion to his alma mater and a certain lack of discrimination, often a product of the hysterical domination of a phase of the college spirit which produces a hypo-sensitiveness in detecting the defects of his own and a corresponding degree of hyper-sensitiveness for picking out those of other institutions. This is one of the reasons why the information acquired by trustees from their friends in the faculty in regard to the relative value of work done in the different departments of the university often has about the same intrinsic worth when introduced as evidence as a Teutonic valuation of French scholarship, or a stand-patter's attitude towards the subject of tariff reform.

The trustees' lack of a clear understanding of the nature of university problems and their failure to cooperate with the faculty in the formulation of a definite policy for the development of the institution, is a very serious tactical error. The public, partly through ignorance, and partly through an instinctive feeling of distrust, caused by the silence of the administration as to the existence of any general plan for the development of the university, does not have any great degree of confidence that funds contributed are always expended to the best advantage.

A public statement of policy would avert another danger always imminent in the administration of university affairs. The acceptance of benefactions with attending conditions may be a curse and not a blessing. The American university has reached a stage in its development when it is no longer to be considered as a debtor to any public-minded, generous citizen who contributes to its financial support. The attitude passively assumed by trustees, that the policy determining the growth of the institution depends upon the sums of money contributed for maintenance, is not only 
undignified, but it is in danger of becoming a thorn in the flesh.

This eringing form of mendicancy, always on the defensive, would cease to exist, if a carefully prepared plan for the future development of the institution was presented to the public. There is no reason why a great university should be apologetic in asking for financial support.

The sense of official obligation which often impels trustees to beg in a perfunctory manner for funds, making it possible to carry some plan or scheme into effect, the details of which are either unknown or are not carefully prepared for general scrutiny, does not generate sufficient strength of conviction among the representatives of the university to arouse by their appeals the interest of intelligent persons to the point when a favorable response may be expected.

Those institutions of learning which take the public into their confidence, at the same time pledging themselves to the maintenance of the highest academic ideals, will without doubt receive the necessary financial support. The resentful attitude sometimes adopted by an administration in the face of the well-directed criticisms from without, is often replaced by a singular indifference or apathy in formulating a working plan embodying any features suggested by those who are not intimately associated with the institution.

Several instances of this tendeney to drift have recently occurred and may be taken as quite typical of what is unfortunately a frequent occurrence. One of the most distinguished scientists in the country offered in writing some suggestions for the development of departments along lines, which, if they had been followed, would have brought signal distinction and honor to a university with which he was not officially connected. The plan has never been discussed by either trustees or faculty, and it is only reasonable to suppose that the genuine interest in the affairs of this particular institution shown by an outsider, whose opinion is highly valued in university circles, has not increased if it has not altogether disappeared.

Very often prominent men are asked to state the conditions upon which they would go to certain universities. Their replies are sometimes given at length and are devoted to indicating the lines along which the work in certain departments should be directed. These replies, containing the valuable advice of experts, are seldom discussed by the faculty or trustees, and the possibility of making a successful public appeal for the carrying on of important work is not entertained. The effect of this lack of sympathetic, intelligent interest of the trustees in the actual progress of the university has become a serious drawback, and is quite as disastrous for the maintenance of high ideals as is the notion that it is possible to estimate the progress of an institution by the increase in the enrollments of students or by an enumeration of the list of new buildings.

The discussions that have occurred in academic circles during the past decade have served the double purpose of exposing defects inherent in the administration of most of our universities and have also been the means of suggesting the remedies. (1) There is a pretty general agreement that the autocratic powers of presidents and of all executive officers should be limited. In order to do this successfully, the conditions responsible for the present state of affairs should be modified. This would lead to setting reforms in motion, resulting eventually in an intelligent and active cooperation of the executives, trustees and faculty. An excellent plan has been suggested of limiting the tenure of office of 
president and deans to a single period of four or five years. The salaries paid to executives should not greatly exceed that of the professors, nor should more elaborate provision be made for the residences of president and deans than for those of the faculty.

(2) Synchronous with the limitations imposed upon the authority of executives there should be corresponding and equally important changes in the board of trustees. A joint committee, as already suggested, consisting of three or five members from each board, viz., trustees and faculty, should act as the medium for keeping the former in touch and sympathy with the intellectual progress of the university. The presiding officer of this joint committee should be chosen by vote from either board and it would be well to limit his tenure of office to correspond with that of the president and deans. The reports of this committee would be quite free from the personal coloring given to the suggestions made by single executives. The establishment of a more intimate relationship would be reciprocally beneficial and would serve to give the faculty a greater sense of responsibility by introducing the discussion of questions of broader academic interest, and would lessen the tendency of individual members of the faculty to indulge in the petty recriminations and personalities which are the result of conditions arising from having lived too long in one place, and a limited intellectual horizon. A change of equally great importance would be the creation of an advisory board to trustees and faculty, composed of the members of the joint executive committee, to which should be added several representatives, preferably from the faculties of other universities. This enlarged committee should hold one or two meetings a year and from its foreign members a perspective view of the university could readily be obtained. The Princetonian should know how his alma mater appears when viewed from Cambridge, and the Harvard professor or overseer could sometimes correct a tendency to spiritual myopia by adopting suggestions coming from a source as distant from the Back Bay as is New Jersey. The tyrannical domination of certain forms of college spirit has become an obstacle to progress in the life of the older universities. Impatient of criticism and often expressing itself in the form of a flabby optimism it insists that the administration of the university should be directed solely by those alumni who possess "the requisite degree of knowledge of local conditions." The annual report of "outsiders" letting in fresh air from without the walls would in time lead the trustees to take a more intelligent appreciation of the intellectual life of the university.

The rate of development of our higher institutions of learning will be directly proportional to the rapidity with which trustees or regents familiarize themselves with the actual progress made in the university world. The majority of trustees on account of lack of knowledge have the tendency to look at university problems from the high-school or collegiate point of view. Their failure, in common with many other persons, to apprehend or appreciate the essential factors in the life of a great university at their proper valuation was referred to by the late President Gilman when he more than once affirmed that "the true university does not depend upon 'cloistered aisles' or a beautiful campus." He knew how often brains are sacrificed for buildings, and that institutions like individuals often built themselves wonderful tombs. If we except what has been accomplished in a few notable instances, there has been a general failure in our 
eastern universities to comprehend the vital importance of encouraging productive scholarship. Business men as a rule have only a vague idea of the reasons for promoting and encouraging research and university trustees greatly need enlightenment on this subject. The mention of the word "investigation", suggests "mysteries," while research is looked upon in the light of a luxury carried on by professors as a pleasant relaxation from the ordinary drudgery of routine duties. This misconception of the spirit that dominates the investigator is a transmitted product of the times when the general public was satisfied to accept the first half of the definition of "university" given in the dictionary; namely, "an institution devoted to teaching."

Recently the reading public has reopened the dictionary and has found there is a second hitherto forgotten clause, "and to the higher branches of learning." Learning and teaching, if either one is to be successful, can not be disassociated. The investigator is a "learner" and teaching, if it is not to degenerate into dogmatism, a mere cramming of the memory with information, must be thoroughly inoculated with the spirit of youth. The instructor, who, in the ordinary sense of the word, is a teacher, an imparter of information, and one never having actually engaged in research, loses his mental plasticity at a much earlier age than the investigator. The spirit of eternal youth is the impetus and moving force of the great investigator. $\mathrm{He}$ is neither satisfied nor quiesced by the mere commands of authority. The apple falls from the tree, the pendulum swings in the cathedral, the blood leaves the heart, circulates through the body and returns to this organ, and his eyes are first to see these phenomena. He needs no "letter from the blind to those who can not see" to arouse his perceptive faculties. His sympathies are with the healthy child, whose interest in the universe has not been impaired by teachers competent only to impart information and constantly irritated by the "why" of irrepressible and impressionable youth. $\mathrm{He}$ does not discourage any attempt to look at the universe from Aristotelian or Platonic point of view, but admonishes the student to be himself rather than a mere pocket edition of the classics.

The basic principle underlying culture, expressed in the affirmation "no one is altogether right and no one altogether wrong," is the working creed of the investigator. His attitude of mind makes him instinctively reject as spurious the cultural specifics hawked in the market-place as cures for all the ills to which human flesh is heir. The invidious distinctions occasionally drawn by teachers, between those subjects which have a supposedly higher cultural value and those of more strictly utilitarian merit do not exist. The mental mechanism determining the individual possession of culture is merely an index of the functional capacity of the brain and nervous system. The factors upon which this mechanism depends are largely the product of racial and ancestral traits. Too much attention is frequently given to the infinitesimal influence of education in the supposed dissemination of these particular mental traits, while some educators are actually in danger of reducing the pursuit of culture to a fad. By proclaiming too vociferously the specific virtue of certain remedies, they not only expose the fallacies in the argument, but like the parvenu who continually harps upon the advantage of aristocracy, they make public confession of the absence in their own cases of the hereditary factors essential in the acquisition of culture. These same persons, says President R. S. Woodward, "having drunk deeply at 
certain fountains of learning appear to be sure that there are no others." The spirit of investigation is a tonic, restoring vigor, self-reliance, and individuality to the members of the army of imitators that yearly receive degrees from our colleges and universities. It rebukes the artist whose chief ambition in life is to copy French models, ridicules the classicist who is only at his best when working in the Oxford atmosphere, or the scientist whose spectacles are made in Germany, and says to each of them, "Eyes have you and can not see, ears and hear not," and with the Persian poet is ready to exclaim, "I myself am Heaven and Hell." Instead of offering to the student an "a la carte" diet of selected facts and theories, it would teach him how to search intelligently for facts while cautioning him as did Bishop Berkeley to "consider the pains that have been taken to perplex the plainest things, that distrust of the senses, those doubts and scruples, those obstructions and refinements that occur in the very entrance of the sciences." If he remembers this admonition then "it will not seem strange that men of leisure and curiosity should lay themselves out in fruitless disquisitions without descending to the particular parts of life, or informing themselves in the more necessary and important parts of knowledge."

The university in which the spirit of research does not pervade the atmosphere bears a relation to the students similar to that of the nursery maids to the children playing on the beach, always within call of guardians, ever ready to emphasize the danger of young people venturing beyond their depth. The desire to enter deep water is more quickly aroused by watching expert swimmers than by reading dissertations on the art of swimming. Youth rebels at the needless restraints imposed by authority, and as an education is generally only the summons bidding it listen with becoming humility to the eommands of the fathers, those in authority should recognize that the assumed indifferences of undergraduates to the claims of the intellectual world is often merely a protective form of reaction. Instead of repressing healthy instincts, why should not students be encouraged to believe that it is possible for them to advance the bounds of our present store of knowledge? The consciousness of leading in the procession always awakens stronger impulses and deeper interests than can be expected to develop in students who in all their mental excursions have been trained like the participants in the parade of a young ladies' boarding-school, to submissively follow the teacher.

The healthy, inspiring and contagious spirit of independence of the modern investigator, recalling that of the old Vikings with their uncontrollable desire to sail over unknown seas, should be fostered by our universities. The presence in these institutions of a large corps of investigators each led by a dominating interest in his special problems, is the sanest and safest method by which to combat "commercialism," ereate idealism and give undergraduates an intelligent appreciation of the pleasures of student life. "Words are feminine, deeds masculine," says the old Italian proverb. The patience of youth has been severely overtaxed by the length and number of the sermons to which it has been forced to listen. To-day the American university has a wonderful opportunity to teach by example. By making the encouragement of productive scholarship a primary and not a secondary duty students may be led to realize that an intelligent, normal interest in any subject is inseparably connected with the desire for progress.

The index of the healthy physical and 
mental life of a great university is measured by the number and activities of its teachers and students who are actually engaged in productive scholarship.

During the period when trustees and regents have been more keenly interested than ever before in discussing the question as to whether the ideals of the high school and college should or should not dominate the policy of the university, two great foundations, the Carnegie and Rockefeller Institutions, have been dedicated to the advancement of learning. Gradually the real significance of their independent existences is becoming more and more apparent to those persons who are competent to form an opinion upon the nature and scope of university problems. The American university to-day is an institution devoted primarily to teaching, while its assumed right to the title of a seat of learning is still open to question. Will the old bottles hold the new wine? If they do not then the intelligent interest of a rapidly increasing number of American citizens, competent to distinguish the essential differences between collegiate and university ideals, will within a few years provide the means for the establishment of "higher institutions of learning."

Stewart Paton

Princeton, N. J.

\section{PHYSIOLOGY AS A FUNDAMENTAL IN VETERINARY EDUCATION ${ }^{1}$}

Education, like nature, should be orderly-a development from the simple to the complex. The development of the morphologically simple cell into the complex adult animal organism proceeds in an orderly way. The cell is the morphological unit and the mature animal consists of in-

\footnotetext{
1 Presented at the meeting of the Association of Veterinary Faculties and Examining Boards of North America at Toronto, Canada, August, 1911.
}

numerable units, some of which have undergone a very great modification as to form. The cell can not be accepted as the physiological unit. What is apparently simple as to form is not necessarily simple as to function. The activities of the cell are but partially understood. The physiological unit, around which center these activities, is, like the atom of chemistry, invisible, but its power is unquestioned. Function is concealed in structure. Function is not often revealed without search and, indeed, research. In some instances it may be so superficial as to be easily recognized; in others it may lie so deeply that the keenest intellect is baffled in demonstrating its presence in a satisfactory manner.

The relation of physiology to the biological sciences is most intimate. It is not a question of independence but of interdependence. Many more or less plausible arguments may be advanced that one particular science may have a greater relative value than others. Chemistry and physics are concerned with matter and we ordinarily associate them with unorganized bodies. Physiology is restricted to living matter, or organized bodies. We can not consider inorganic material in physiological terms. Yet chemistry and physics are intricately involved in physiological processes and the question arises, perhaps, in the minds of some if, under the proper combination of conditions and of environment, life is not evolved from chemical reactions. Chemical action is constantly occurring in living tissue. Does it control the living tissue or does the living tissue control it? In the processes of filtration, diffusion and osmosis, physics occupies a relationship scarcely less intimate than chemistry. Solutions of crystallizable substances of unequal concentration separated by an animal mem- 